\title{
Performance Investigation of Batch Mode Microbial Fuel Cells Fed With High Concentration of Glucose
}

\author{
Xiaoying Kong, Gaixiu Yang and Yongming Sun* \\ Guangzhou Institute of Energy Conversion, Key Laboratory of Renewable Energy and Gas Hydrate, Chinese Academy of Sciences, China
}

Received: March 05, 2018; Published: March 16, 2018

*Corresponding author: Yongming Sun, Guangzhou Institute of Energy Conversion, Key Laboratory of Renewable Energy and Gas Hydrate, Chinese Academy of Sciences, Guangzhou, China, Tel: 86-020-87057009; Email: sunym@ms.giec.ac.cn

\begin{abstract}
Two-chambered microbial fuel cell (MFC) with Nafion117 as proton exchange membrane (PEM) in the middle of reactors was built to treat the synthetic wastewater containing high concentration of glucose in this work. This MFC can produce $95 \%$ removal efficiencies of the maximum chemical oxygen demand (COD) and the highest coulombic efficiency (Ec) of $24.4 \%$ at the glucose concentration of $1 \mathrm{~g} / \mathrm{L}$. It was found that when the feed of glucose concentration is changed from $0.5 \mathrm{~g} / \mathrm{L}$ to $4.0 \mathrm{~g} / \mathrm{L}$ the volumetric power density is decreased from $5.3 \mathrm{~W} /$ $\mathrm{m}^{3}$ to $2.25 \mathrm{~W} / \mathrm{m}^{3}$. When the glucose concentration is further increased to $12 \mathrm{~g} / \mathrm{L}$, almost no power output was observed. The optimized running concentration of glucose for as-designed MFC is between $0.5-4 \mathrm{~g} / \mathrm{L}$ at the experimental conditions in this work. This work would pave a way for the direct treatment of wastewater containing high concentration of complex organic contaminants.
\end{abstract}

Keywords: Microbial Fuel Cell; Wastewater Treatment; High Substrate Concentration; Glucose

Abbreviations: MFC: Microbial Fuel Cell; PEM : Proton Exchange Membrane; COD: chemical oxygen demand; HPLC: High-Performance Liquid Chromatography; PBS: Phosphate Buffered Solution; VFA: Volatile Fatty Acid

\section{Introduction}

Due to the capability of converting chemical energy stored in a variety of biodegradable materials from pure compounds, such as glucose and mixtures of organic waste to the electrical energy via exoelectrogenic bacteria directly, MFC as a promising and novel supply of the green energy have been attracting more and more attention in the recent years [1]. In MFC, the electrons are firstly transferred to the anode from the organic substrate through a complex respiratory chain of specific microorganisms in the present or absent of redox mediator of exogenous or natural secretion of bacteria and then to the selected terminal electron acceptor, such as 02 in aerated solution or ferricyanide cathode et al. The integrated external circuit for power generation would be matched with the equal number of protons in solution migrating from anolyte to catholyte [2-4].

Mixed microbial communities are expected to be able to utilize more complicated carbon sources at the same time and achieve substantially greater power density than that of pure microbial. This is desirable for energy harvest from wastewater with an advantage in the combination of wastewater treatment along with electricity production [5]. It is recognized recently that the electricity produced by MFC may never be a cost effective source of energy since MFC built in the previous experiments could only produce $50 \mathrm{~mW} / \mathrm{m}^{2}$ power densities, which is less than other types of fuel cells and is far away from commercialized need [6-8]. Their contribution is to propose a method for reducing the energy used in wastewater treatment in comparison with conventional aerobic technology $[9,10]$. Demonstrated for the first time that power densities obtained using actual domestic wastewater as the substrate in MFC with a single-chambered air cathode could reach

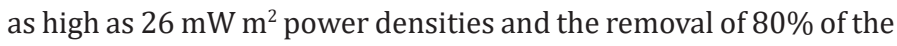
COD of the wastewater.

This initiated much effort to explore the possibility for MFC to be economically applied in wastewater treatment [11]. Studies from Logan group showed that using the rational configuration innovation of MFC with an air-cathode single chamber and without a proton exchange membrane, power output could be increased rapidly for different sources of wastewater. The maximum power densities are $261 \mathrm{~mW} / \mathrm{m}^{2}$ for the swine wastewater, $205 \mathrm{~mW} /$ $\mathrm{m}^{2}$ for brewery and $146 \mathrm{~mW} / \mathrm{m}^{2}$ for the domestic wastewater. These are much higher than $26 \mathrm{~mW} \mathrm{~m}^{-2}$ mentioned above [12-15]. Reported that when MFC with a baffled air-cathode was used to treat the wastewater from corn stover steam explosion process, 
the maximum power density of $10.7 \mathrm{~W} / \mathrm{m}^{3}$ with the average COD removal rate to $89.1 \%$ was obtained recently, studies of [16], Showed that MFC technology is effective to treat chocolate industry wastewater as an alternative approach. The simultaneously generated current reached $3.02 \mathrm{~A} / \mathrm{m}^{2}$ coupled with significant reduction in COD, BOD and total solids of wastewater. However, to become economically competitive with stable power output of $1 \mathrm{~kW}$ $\mathrm{m}^{-3}$ per reactor [17]. Many technological improvements still need to be made in the near future.

As described in previous studies, apart from the system architecture, the bacterial community, the electrode material and the substrate sources et al, the performances of MFC was widely changed with the operating conditions, especially with the substrate concentration [18-20]. Presented that power output follows the saturation-type kinetics when the substrate concentration is less than $1 \mathrm{~g} / \mathrm{L}$. However, few data showed the performance index and operational mechanism of MFC fed with substrate concentration higher than $1 \mathrm{~g} / \mathrm{L}$, which is particularly beneficial for high-strength industrial wastewater treatment in positive market value. In this study, MFC running under high concentration of glucose was firstly investigated; the overall function and efficiency were estimated through its power density, Ec and removal rate of COD during the experimental period. The obtained results can be used to explain how the substrate concentration impacts on the work efficiency of MFC and to demonstrate that MFC is prosperous in the application of the direct treatment of wastewater containing high concentration of complex organic contaminants.

\section{Materials and Methods \\ MFC Configuration}

MFC with two-chambers in cubic geometry was constructed using plane Plexiglas as previously described [21]. Both anode and cathode chambers have the same volume, $500 \mathrm{~mL}(10 \mathrm{~cm} \times 10 \mathrm{~cm} \times 5$ $\mathrm{cm}$ in height) and are separated by PEM (Nafion117, Sigma-Aldrich). Prior to use, PEM was first successively treated with boiling in sequence of $30 \% \mathrm{H} 2 \mathrm{O} 2$, deionized water, $0.5 \mathrm{M} \mathrm{H}_{2} \mathrm{SO}_{4}$ and deionized water about one hour each for enhancing the porosity. Perforated graphite plate (30 holes per $3.14 \mathrm{~mm}^{2}$ ) was used as anode for increasing the surface area to facilitate effective electron transfer to the selected terminal electron acceptor, hexacyanoferrate. The anode was prepared with carbon cloth covered with carbon felt for better bacterial adhesion. Ti wires sealed with epoxy were used for connection between electrode and external circuit with fixed external resistance of 510 冈. Each chamber was provided with purging, sampling, wire point inputs (top), inlet and outlet ports. The ports were sealed with thick rubber stoppers during operation. The anode compartment was sealed with washers to ensure anaerobic microenvironment. Before use, the electrodes were soaked in deionized water for at least $24 \mathrm{~h}$. All related materials were sterilized with the bleach solution.

\section{Media and Microorganisms}

The anode compartment of MFC was inoculated with activated sludge initially collected from the bottom of Yudai River at Panyu,
Guangdong Province, China with mixed bacterial consortia. The anodic electrolyte is the phosphate buffered solution (PBS; $\mathrm{pH}=7$ ) including $\mathrm{Na}_{2} \mathrm{HPO}_{4}, 12.8 \mathrm{~g} / \mathrm{L} ; \mathrm{KH}_{2} \mathrm{PO}_{4}, 3 \mathrm{~g} / \mathrm{L}$ and $\mathrm{NH}_{4} \mathrm{Cl}, 1 \mathrm{~g} / \mathrm{L}$. Glucose is used as a substrate with $0.5 ; 1.0 ; 2.0 ; 3.0 ; 4.0 ; 8.0$ and $12.0 \mathrm{~g} / \mathrm{L}$ concentration respectively, according to the research need in our experiments. Ferricyanide is chosen as an abiotic cathode and the cathodic electrolyte contains $\mathrm{Na}_{2} \mathrm{HPO}_{4}, 12.8 \mathrm{~g} / \mathrm{L} ; \mathrm{KH}_{2} \mathrm{PO}_{4}, 3 \mathrm{~g} / \mathrm{L}$ and $\mathrm{K}_{3} \mathrm{Fe}(\mathrm{CN}) 6,16.5 \mathrm{~g} / \mathrm{L}$ as a terminal electron acceptor.

\section{Experimental Procedures and Calculations}

Glucose-Fed MFC with a quite wide range of substrate concentrations is operated under batch mode at a proper external load. The anodic chamber is flushed with nitrogen gas for at least 30 min before each experiment to remove dissolved oxygen, leading to an anoxic condition in the reactor. Fresh ferricyanide dissolved in PBS was added once the voltage output dropped abruptly to a relative low value, which was due to the evaporation loss or reduction of ferricyanide concentration. When the MFC still could not restore its function the cathodic and anodic electrolytes should be replaced, indicating the end of one complete cycle of operation and the start of a new cycle. The overall performance of MFC is evaluated through the start up time, power output, COD removal rate and Ec et al.

Some calculation equations are as follows:

$$
I=U / R
$$

Where I is the current, $\mathrm{U}$ is the cell voltage, the $\mathrm{R}$ is the external resistor, set at 510 区.

$$
P=U^{2} / R
$$

Where $\mathrm{P}$ is the power output,

$$
P_{V}=P / V
$$

Where $\mathrm{P}_{\mathrm{V}}$ is the volumetric power density. $\mathrm{V}$ is the volume of anodic chamber.

$$
P_{A}=P / A
$$

Where $\mathrm{P}_{\mathrm{A}}$ is the surface area power density, $\mathrm{A}$ the anode surface area.

Under variable external resistance, a series of steady-state voltage and corresponding calculated current were collected for a polarization curve, which was used to acquire the maximum power density.

$$
U=e m f-I r
$$

Where emf is the electromotive force, $r$ is the internal resistance.

Obviously, for the polarization curve (U-I), in the straight line portion, the slope equals to - r, while the intercept corresponds to emf.

$$
E c=C p / C T^{\prime} 100 \%
$$

Where Ec is the coulombic efficiency, $\mathrm{Cp}$ is the total coulomb, $\mathrm{CT}$ is the theoretical coulomb.

$$
E_{E}=E p / E T^{\prime} 100 \%
$$

Where $E_{\mathrm{E}}$ is the overall energy recovery, Ep is total obtained energy, ET is theoretical energy produced from the added glucose. 
To monitor the volatile fatty acid (VFA) accumulating during the operation of MFC, the samples taken from the anode compartment at the end of each running cycle are centrifuged at $5000 \mathrm{rpm}$ under lower temperature of $0-4^{\circ} \mathrm{C}$. Then, the supernatant is collected and filtered through a sterile syringe filter $(0.22 \rrbracket \mathrm{m})$ for the analysis of mechanic acid, acetic acid, propionic acid, is butyric acid, is ovaleric acid and ethanol et al. using high-performance liquid chromatography (HPLC) through the detected weight per volume of each component. In the selected HPLC system (Waters2695) with Refractive Index Detector (Waters2414), Shodex Rspak KC811 S-DVB gel Column in the size of $30 * 8 \mathrm{~mm}$ is utilized while $1 \%$ phosphoric acid as eluent at $0.7 \mathrm{~mL} / \mathrm{min}$ flow rate. The column temperature and the injected sample volume are set at 40凶C and $10 \bigotimes \mathrm{L}$, respectively. The collected sample is also used for COD detection according to the regular method previously reported [11].

\section{Results and Discussion}

\section{Acclimation of Bacteria to Glucose in Different Initial Concentration}

Figure 1 shows the effects of glucose concentration on the performance of MFC: The as-designed MFC is initiated by introducing synthetic wastewater as the carbon source, various concentrations of glucose from $0.5-20 \mathrm{~g} / \mathrm{L}$ and active sludge as a source of exoelectrogenic bacteria to the anode compartment with external resistance fixed at 510区. It was found from Figure 1 that Table 1: Comparison of the performance of MFCs operated at various glucose concentrations.

\begin{tabular}{|c|c|c|c|c|c|c|}
\hline Glucose concentration(g/L) & 0.5 & 1 & 2 & 3 & 4 \\
\hline open circuit voltage (V) & 0.823 & 0.823 & 0.744 & 0.735 & 0.672 & 0.638 \\
\hline Start-up time(day) & 2 & 3 & 6 & 10 & 12 \\
\hline Internal resistance & 86.75 & 97.53 & 137.42 & 152.03 & 193.12 & 656.09 \\
\hline emf & 0.7645 & 0.6647 & 0.7166 & 0.707 & 0.7024 & 0.8908 \\
\hline
\end{tabular}

The slow-down cell response might be linked to the limited transport rate of fuels to bacteria due to the decreased concentration gradient of the substrate. For glucose at $4 \mathrm{~g} / \mathrm{L}$, the start-up time is as long as 10 days. However, MFC can run at maximum power for more than 15 days, which is much longer that at any other concentration mentioned above. When the glucose concentration is in the range between 4 and $8 \mathrm{~g} / \mathrm{L}$, the MFC behaves unstable as indicated. For instance, for $12 \mathrm{~g} / \mathrm{L}$ glucose, the generated maximum cell voltage is less than $0.3 \mathrm{~V}$ with much longer start-up time of more than 20 days. Furthermore, for glucose at the concentration higher than 16 $\mathrm{g} / \mathrm{L}$, no observable power is obtained. This might contribute to the inhibition of substrates in high concentration to the growth of the electro active microorganisms.

These results present that substrate concentration has important influence on the performance of MFC. The optimal concentration of glucose at the experimental conditions is about 0.5-4 $\mathrm{g} / \mathrm{L}$, based on the start-up time and the running time kept at maximum voltage output. The substrates concentration is less than $0.5 \mathrm{~g} / \mathrm{L}$, the start-up tine of MFC is faster. However, the running cycle is proved to be shorter, leading to larger workload during wastewater treatment since more frequent refreshment of when the concentrations of glucose is less than $4 \mathrm{~g} / \mathrm{L}$, the stable electricity could produce without adding redox mediator. The startup time is varied for different concentration of glucose as shown in (Table 1). The bacteria easily adapted to glucose at $1 \mathrm{~g} / \mathrm{L}$ in 2 days with cell voltage output leveled off at $0.63 \mathrm{~V}$ and sustained for 9 days. After substrate solution was refilled, voltage output is recovered quickly to $0.65 \mathrm{~V}$. In contrast, when glucose concentration is lower than $0.5 \mathrm{~g} / \mathrm{L}$, the daptation time of 4 days is needed and the maximum voltage is $0.6 \mathrm{~V}$ kept for about 3 days.

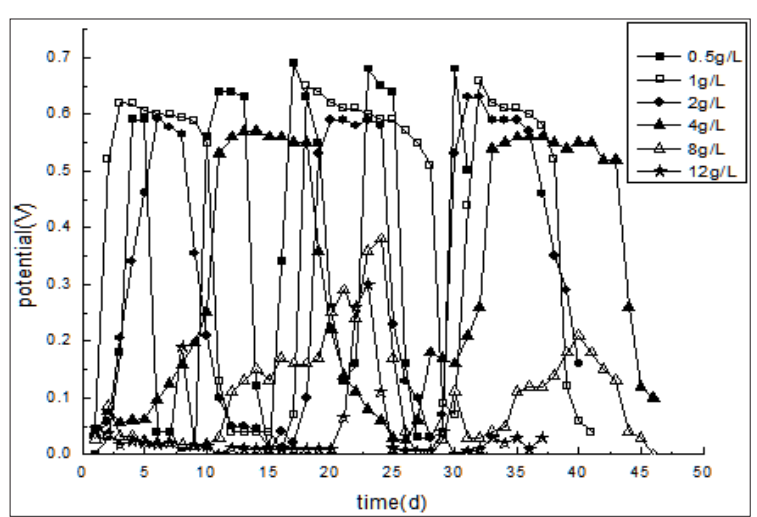

Figure 1: The relationship curves between cell voltage and time for two-chambered MFCs fed with different glucose concentrations under external resistance fixed at 510区. substrates might required. When glucose concentration is larger than $4 \mathrm{~g} / \mathrm{L}, \mathrm{MFC}$ does not work very well with quite long adaptation time and lower power output. Even no electricity produced when the glucose concentration is higher, due to the substrate inhibition. These would be further demonstrated by other parameters, such as internal resistance, maximum power density, $\mathrm{E}_{C}$ and COD removing rate et al. as discussed in follows.

\section{Effect of Glucose Concentration Upon Power Generation}

Figure 2 represents the U-I polarization curve when MFC ran properly at its maximum voltage output under different initial fuel concentration. The internal resistance and electromotive force in each test obtained from Figure 2 are summarized in (Table 1). It was found from Table 1 that when the glucose concentration changes from $0.5 \mathrm{~g} / \mathrm{L}$ to $4 \mathrm{~g} / \mathrm{L}$ the internal resistance is changed from 47.8 to $99 \square$ and the electromotive force is decreased from $0.75 \mathrm{~V}$ to $0.64 \mathrm{~V}$. When the more glucose is added to the anodic electrolyte it becomes more sticky, leading to worse mass transport efficiency affecting both bacteria and proton transfer from anode to cathode. This might be the reason for the significant raise in internal resistance with increase of glucose concentration in the anode chamber. When the glucose concentration changes from 0.5 
$\mathrm{g} / \mathrm{L}$ to $4 \mathrm{~g} / \mathrm{L}$ emf is decreased from 0.7645 to $0.7024 \mathrm{~V}$. This may be due to that when MFC was fed with different concentration of glucose bacteria may be easily adapted to glucose. Why bacteria may be easily adapted to glucose emf will reduce Figure 3 shows the relationship curves between power density and cell voltage for the different glucose concentration.

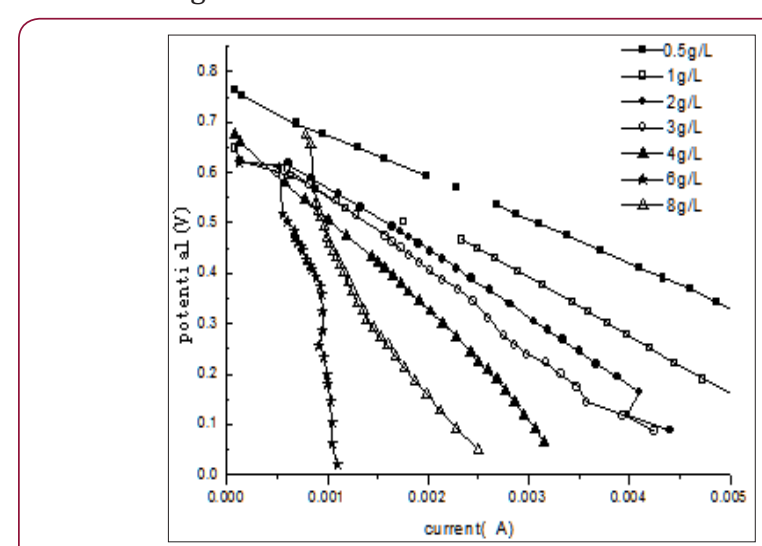

Figure 2: U-I polarization curves for MFCs running at different initial glucose concentrations.

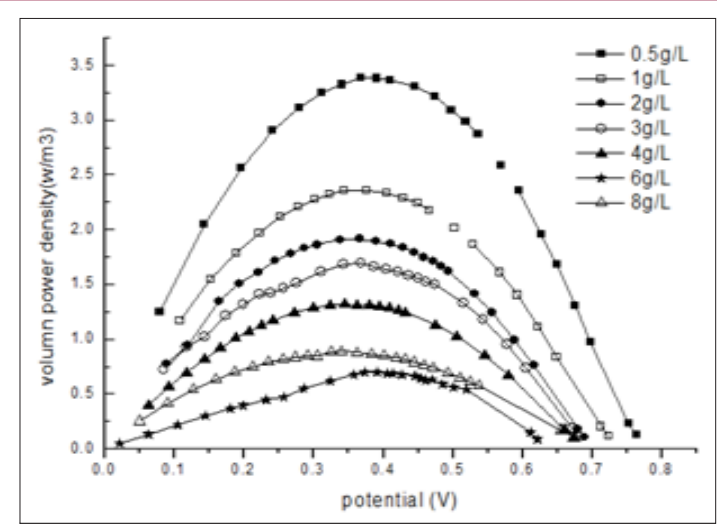

Figure 3: The relationship curves between power density and cell voltage for the different initial glucose concentration.

The shapes of the power density curves for MFC fed with various initial glucose concentrations are the same (Figure 3). However the maximum volumetric power density dropped down distinctively with the increase in the glucose concentration. For example, when the glucose concentration is increased from 0.5 to 4 $\mathrm{g} / \mathrm{L}$ the maximum volumetric power density is decreased from 5.3 to $2.25 \mathrm{~W} / \mathrm{m}^{3}$. This is quite different from the saturation kinetics modeled with an empirical Monod-type equation. Basically, for overfeeding, the available substrate is theoretically far beyond the oxidation capabilities of the existing exoelectrogenic bacteria in the anode compartment. Large amount of extra glucose might promote the growth of fermentative bacteria faster than those of the anodophiles in a mixed culture. This could be further demonstrated by the decreased EC and accumulated more and more variety of volatile fatty acids detected during MFC operation as shown in the next session. It is reasonable to conclude that the decrease in power output with the increase in glucose concentration at higher level contributed to the diverse consumption of substrates by fermentation and methanogenesis et al. and their further negative effect on the metabolisms, even species distribution of electroactive bacteria through generated inhibitor, such as propionic acid et al.

\section{Substrate Degradation and Coulombic Recovery}

When MFC is fed with different initial concentration of substrate at the high level the final COD removal efficiency is kept around 84$95 \%$ detected at the end of the experiments since voltage output less than $0.03 \mathrm{~V}$ as shown in (Table 2). However, the overall calculated Ec was relatively quite low ranging from $16.8 \%$ to $24.4 \%$ for all different concentration of fed fuels, implying most of the substrate degraded by non-exoelectrogenic organisms through diverse competing metabolisms, such as fermentation and methanogenesis. This is further demonstrated by the observed corresponding byproducts of various VFA accumulated during the operation of MFC under fed glucose greater than $1 \mathrm{~g} / \mathrm{L}$ as summarized in (Table 3 ). The obtained Ec and COD removal efficiency did not simply increase in proportion to the fed glucose concentration. At lower concentration of glucose less than $1 \mathrm{~g} / \mathrm{L}$, Ec increased from $23.44 \%$ at $0.5 \mathrm{~g} / \mathrm{L}$ to $24.36 \%$ at $1 \mathrm{~g} / \mathrm{L}$, while COD removal efficiency improved by $11 \%$. However, when the added fuel concentration is higher than $1 \mathrm{~g} / \mathrm{L}$, Ec is decreased by $7.6 \%$ from $1 \mathrm{~g} / \mathrm{L}$ to $4 \mathrm{~g} / \mathrm{L}$ and COD removal efficiency is decreased from $95 \%$ at $1 \mathrm{~g} / \mathrm{L}$ to $90 \%$ at $4 \mathrm{~g} / \mathrm{L}$ with extended running time of 12 hours. This might be ascribed to the switches of fermentations from acetic to mixed acids with the increase in the concentration of fed fuels from $1 \mathrm{~g} / \mathrm{L}$ to $8 \mathrm{~g} / \mathrm{L}$, as indicated in (Table 3). Resulting in more and more accumulated propionic acid. At high concentration of more than $1 \mathrm{~g} / \mathrm{L}$, propionic acid was reported to cause obvious inhibition of anaerobic bacteria and consequently affect the activity of these bacteria [22]. Interestingly, when fed glucose at concentration lower than $0.5 \mathrm{~g} / \mathrm{L}$, no any VFA is detected. When the concentration is between $0.5 \mathrm{~g} / \mathrm{L}$ and $2 \mathrm{~g} / \mathrm{L}$, only acetic acid is found. This might be one of the reasons why the performance of glucose-fed MFC enhanced with the increase in the substrate concentration at low level. It is possible that glucose is firstly converted into more effective degradable substrate of acetic acid for MFC by glucose-degrading acetogenic bacteria.

Table 2: COD removal efficiency and Ec of MFC at different concentration of glucose.

\begin{tabular}{|c|c|c|c|c|}
\hline Glucose concentration (g/L) & 0.5 & 1 & 2 & 4 \\
\hline Initial value of COD & 330 & 641 & 1167 & 3632 \\
\hline Final value of COD & 52 & 30 & 8 & 104 \\
\hline Duration of operation (day) & 8 & 8 & 94 & 90 \\
\hline COD removal efficiency (\%) & 84 & 95 & 18.98 & 16.79 \\
\hline Ec (\%) & 23.44 & 24.36 & & \\
\hline
\end{tabular}


Table 3: Concentration of various detected volatile fatty acid, accumulated during the operation of MFCs fed with different concentration of glucose.

\begin{tabular}{|c|c|c|c|c|c|c|}
\hline $\begin{array}{c}\text { Initial glucose } \\
\text { concentration } \\
\text { (g/L) }\end{array}$ & $\begin{array}{c}\text { Formic acid } \\
\text { (mg/L) }\end{array}$ & acetic acid (mg/L) & Glucose (g/L) & $\begin{array}{c}\text { propionic acid } \\
\text { (mg/L) }\end{array}$ & $\begin{array}{c}\text { isobutyric acid } \\
\text { (mg/L) }\end{array}$ & \begin{tabular}{l} 
Lactic acid (mg/L) \\
\hline 0.5
\end{tabular} \\
\hline 1 & & 271.128 & 0.286 & & & \\
\hline 2 & 103.263 & 220.578 & 1.318 & & & 320.617 \\
\hline 3 & 131.026 & 960.841 & 2.925 & 115.322 & & 272.109 \\
\hline 4 & 320.783 & 650.946 & 2.535 & 152.089 & & \\
\hline 6 & & 603.118 & 3.723 & 446.380 & & \\
\hline 8 & 76.363 & 909.788 & 4.908 & 264.776 & 651.575 & \\
\hline
\end{tabular}

\section{Conclusion}

This study demonstrated that two-chambered MFC, running in batch mode, behaved quite different for the different concentrations of the synthetic wastewater. When the concentration of glucose is between $0.5 \mathrm{~g} / \mathrm{L}$ and $20 \mathrm{~g} / \mathrm{L}$, the detected voltage output, calculated power density and Ec et al. do not follow the saturation kinetics as a function of substrate concentration for the concentration of glucose less than $1 \mathrm{~g} / \mathrm{L}$. Based on the experimental results presented above, the optimal concentration for glucose is about $0.5-4 \mathrm{~g} / \mathrm{L}$, according to the start-up time, the running time kept at maximum voltage output, the maximum power output and Ec et al.

\section{Acknowledgement}

This work was supported by National Natural Science Foundation. Guangdong Province achievement utilization project (No.2017B020238005); China Academics of Sciences: The 2017 annual international partnership- The Belt and Road special project (No.182344175820170009).

\section{References}

1. Logan BE, Regan JM (2006) Microbial fuel cells challenges and applications. Environ Sci Technol 40: 5172-5180.

2. Yuan Y, Zhang B, Zhou SG, Zhong SK, Zhuang L (2011) Electrocatalystic activity of anodic biofilm responses to $\mathrm{pH}$ changes in microbial fuel cells. Bioresource Technol 102: 6887-6891.

3. Logan BE, Regan JM (2006) Electricity-producing bacterial communities in microbial fuel cells. Trends in Microbiology 14(12): 512-518.

4. Schröder U (2007) Anodic electron transfer mechanisms in microbial fuel cells and their energy efficiency. Phys Chem Chem Phys 9: 26192629.

5. Logan BE (2009) Exoelectrogenic bacteria that power microbial fuel cells. Nature Reviews Microbiology 7: 375-381.

6. Bond DR, Lovely DR (2003) Electricity production by Geobacter sulfurreducens attached to electrodes. Appl Environ Microbiol 69: 15481555.

7. Kim BH, Park DH, Shin PK, Chang IS, Kim HJ (1999) Mediatorless biofuel cell. US Patent 5976719.

8. Tender LM, Reimers CE, Stecher HA, Holmes DE, Bond DR, et al. (2002) Harnessing microbially generated power on the seafloor. Nat Biotechnol 20(8): 821-825.

9. Cheng SA, Liu H, Logan BE (2006) Power Densities Using Different Cathode Catalysts (Pt and CoTMPP) and Polymer Binders (Nafion and
PTFE) in Single Chamber Microbial Fuel Cells. Environ Sci Technol 40: 364-369.

10. Liu H, Logan BE (2004) Electricity generation using an air-cathode single chamber microbial fuel cell in the presence and absence of a proton exchange membrane. Environ Sci Technol 38: 4040-4046.

11. Deepak Pant, Gilbert, V Bogaert, Ludo Diels, Karollen V Broekhoven (2010) A Review of substrates used in microbial fuel cells (MFC) for sustainable energy production. Bioresource Technol 101: 1533-1543.

12. Kim JR, Min B, Loga BE (2005) Evaluation of procedures to acclimate a microbial fuel cell for electricity production. Appl Microbiol Biotechnol 68: 23-30.

13. Feng, $Y$ Wang, $X$, Logan, BE, Lee H (2008) Brewery wastewater treatment using air-cathode microbial fuel cells. Appl Microbiol Biotechnol 78: 873-880.

14. Liu H, Ramnarayanan R, Logan BE (2004) Production of electricity during wastewater treatment using a single chamber microbial fuel cell. Environ Sci Technol 38: 2281-2285.

15. Feng Y, Lee H, Wang X, Liu Y, He W (2010) Continuous electricity generation by a graphite granule baffled air-cathode microbial fuel cell. Bioresource Technol 101(2): 632-638.

16. Patil SA, Surakasi VP, Koul S, Ijmulwar S, Vivek A, et al. (2009) Electricity generation using chocolate industry wastewater and its treatment in activated sludge based microbial fuel cell and analysis of developed microbial community in the anode chamber. Bioresource Technol 100 (21): 5132-5139.

17. Rabaey K, Verstraete W (2005) Microbial fuel cells: novel biotechnology for energy generation. Trends Biotechnol 23(6): 291-298.

18. Jadhav GS, Ghangrekar MM (2009) Performance of microbial fuel cell subjected to variation in $\mathrm{pH}$, temperature, external load and substrate concentration. Bioresource Technology 100: 717-723.

19. Min B, Kim JR, Oh SE, Regan JM, Logan BE (2005) Electricity generation from swine wastewater using microbial fuel cells. Water Res 39(20): 4961-4968.

20. Liu H, Cheng S, Logan BE (2005) Production of electricity from acetate or butyrate using a single-chamber microbial fuel cell. Environ Sci Technol 39(2): 658-662.

21. Kong XY, Sun YM, Yuan ZH, Li D, Li LH, et al. (2010) Effect of cathode electron-receiver on the performance of microbial fuel cells. Int J Hydrogen Energy 35: 7224-7227.

22. Wang YY, Zhang YL, Wang JB, Meng L (2009) Effects of volatile fatty acid concentrations on methane yield and methanogenic bacteria. Biomass and Bioenergy 33(5): 848-853. 
(c) (1) This work is licensed under Creative

Submission Link: https://biomedres.us/submit-manuscript.php

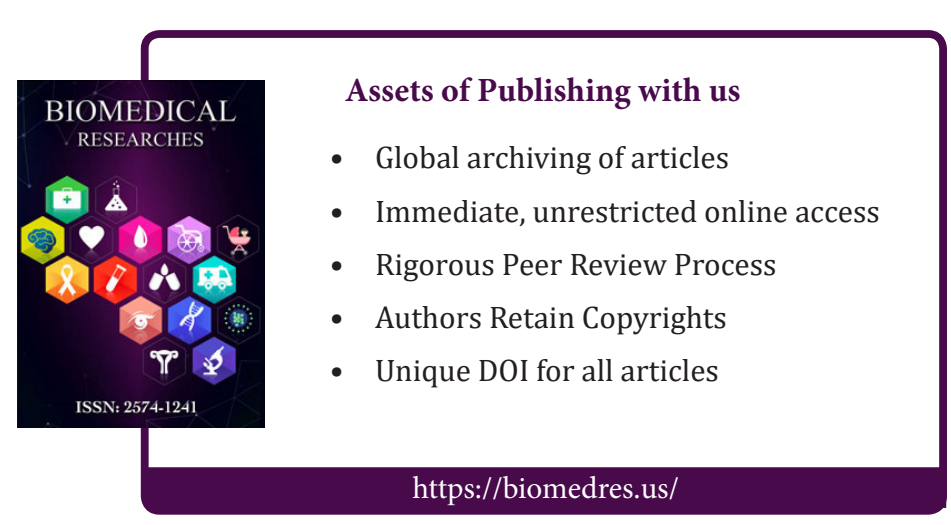

